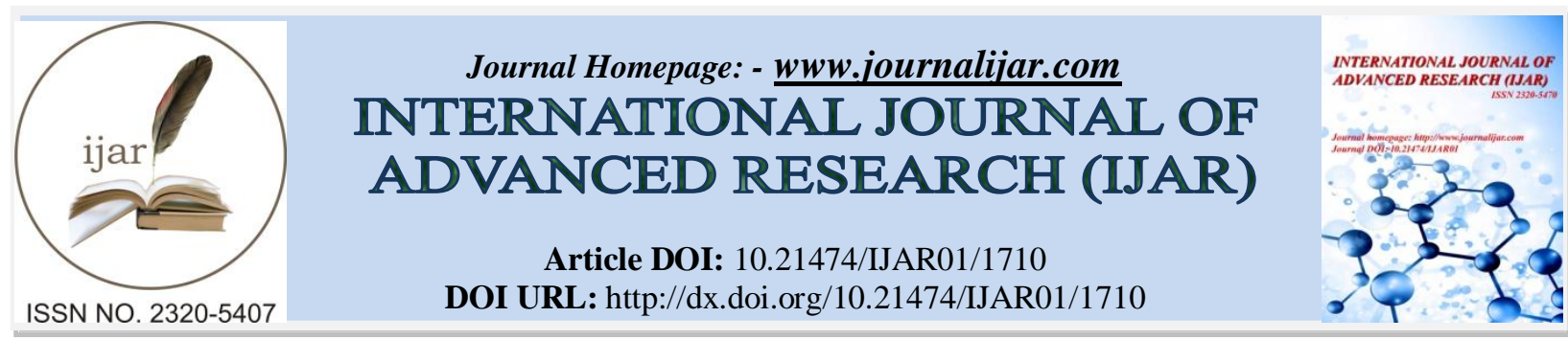

RESEARCH ARTICLE

\title{
A CRITICAL STUDIES OF HUMAN RIGHTS CRIME IN INDONESIAN CRIMINAL SYSTEM.
}

Dedy Siswadi, Muhammad Ashri, Abdul Razak, and Abdul Maasba Magassing. Attorney General of Republik Indonesia.

\section{Manuscript Info}

(..........................

Manuscript History

Received: 12 July 2016

Final Accepted: 19 August 2016

Published: September 2016

Key words:-

Constitutional Rights, Extraordinary

Crime, Human Rights

\section{Abstract}

World Conference on Human Rights in Vienna in 1993 to develop a broad perspective on the human rights implications also on the scope of human rights violations. Recognition of human rights comprising civil, cultural, economic, political and social are interrelated addressed to the responsibilities of the various private and state actors. Indonesia through the legal arrangements of human rights violations as defined in Law No. 39 Year 1999 had followed the universal perspective. Recognized or not, serious human rights violations such as crimes against humanity in practice have occurred in Indonesia. Indonesian authority need to encourage a more serious law enforcement officers in law enforcement gross human rights abuses, lest completeness of the laws and the agencies not only as "cosmetic" of human rights. People really looking forward to the government in terms of the law enforcement of human rights, especially on the "political will" of the government to upholds human rights as a constitutional rights.

Copy Right, IJAR, 2016,. All rights reserved.

\section{Introduction:-}

Crimes against humanity are extraordinary crimes. The law of crimes against humanity has primarily developed through the evolution of customary international law. ${ }^{1}$ Some crimes are particularly grave offences of concern to the world community as a whole. They may occur in the context of war or as part of a larger pattern of aggressive behaviour by powerful actors within a society. These crimes are often directly linked to abuse of political or military systems or to a lack of effective state institutions. Such crimes, which can be referred to as universal crimes, are also attacks on the rule of law and on human dignity.

Indonesia is now facing the important moment of constructing a new foundation as a democratic state. Law enforcement of human rights in Indonesia has made progress, as seen through the amendment of the 1945 Constitution of the Republic of Indonesia as a highest law. The original text of the 1945 Constitution only contains six provisions that explicitly talk about human rights with 15 Human Rights Principles included. ${ }^{2}$

1 Margaret M. DeGuzman,"Crimes against Humanity". Research Handbook On International Criminal Law, Bartram S. Brown, ed., Edgar Elgar Publishing, 2011.

${ }^{2}$ See Todung Mulya Lubis, In Search of Human Rights: Legal-Political Dilemmas of Indonesia's New Order, 19661990 (1994). 
Apparently, however, since the human rights activists and experts strongly opposed this principle and advocated bringing the human rights violators into court, Indonesian government has ratified the Law on Human Rights Tribunal, Law regarding Human Rights, Law No. 39 Year 1999, and there is also Law No. 26 Year 2000 that put aside the non-retroactive principle for gross violation of human rights.

More than that, beside on the legislation approach, Indonesia also has the National Commision on Violence against Women and the Indonesian Commission on Child Protection, as an effort to realize the protection of human rights. But in practical terms, however, it has certain weaknesses, particularly in view of the accountability and legitimacy aspects of its establishment. As it turns out in practice, the number of cases of human rights violations continue to grow without being followed by legal proceedings.

Article 1 point 6 of the Law No. 39 Year 1999 also guarantees that the violation of human rights is any act of a person or group of persons including the state apparatus either intentionally or unintentionally, or negligence unlawfully reduce, impede, restrict, or deprive human rights of a person or group he who is guaranteed by this Act and not get or feared would not obtain legal settlement is fair and correct, based mechanism applicable law.

The formulation regarding the violation of human rights above, according to Slamet Titon, less precise because theoretically does not refer to the concept of human rights normative power of the state as a main problem. The concept of human rights aims to prevent possible abuse of authority and power cursive state, so that the phrase "a person or group of persons" must be replaced on the violation of human rights and state power, then there are two types of human rights violations, namely the action (commission) and settlement (omssion), i.e when the violations committed by indivindu or group of people who are not the state, but the state through the state apparatus does not act, both preventive as well as repressive approach. ${ }^{3}$

However, this view does not seem completely relevant to the development of the current law. It is true that the context of human rights protection is largely associated with power, but did not rule out the offense was committed by a person or group of persons of non-governmental. It is already stated by Titon itself in formulating violations in the form of habitation (omission) by the state, namely against acts of human rights violations committed by the person or group of non-governmental.

That statement is corroborated by the views of Romli Atmasasmita who see human rights violations from the point of substance not only by whom and to whom. Romli stated that the essence of human rights abuses is not merely a violation of the law (legislation), but degradation against humanity or degrading treatment and human dignity be as low as animals.

Moreover, in any human rights violations there are elements of planning, done systematically in a certain way and with a specific purpose, and addressed to a particular object that is more collective, whether based on religion, ethnicity, etc. Although it is seems more collective. ${ }^{4}$

World Conference on Human Rights in Vienna in 1993 to develop a broad perspective on the human rights implications also on the scope of human rights violations. Recognition of human rights comprising civil, cultural, economic, political and social are interrelated addressed to the responsibilities of the various private and state actors. ${ }^{5}$ Indonesia through the legal arrangements of human rights violations as defined in Law No. 39 Year 1999 had followed the universal perspective.

3 Titon Slamet Kurnia. (2005). Reparasi terhadap Korban Pelanggaran HAM di Indonesia. Jakarta: PT Citra Aditya Bakti. Page. 8

$4 \quad$ Romli Atmasasmita. (2000). Pengantar Hukum Pidana Internasional, Jakarta: Refika Aditama, page 175

$5 \quad$ Al Dueck as cited by M.M Billah on "Tipologi dan Praktek Pelanggaran hak asasi manusia di Indonesia." Papers prepared for and presented at the National Legal Seminar VIII Year 2003 with the theme "Law Enforcement in the Era of National Sustainable Development" which was organized by the Legal Development Agency Nasinal Ministry of Justice and Human Rights RI, July 14-18, 2003 in Denpasar, page 6. 


\section{Identification of the Issue:-}

The issue to be discussed in this paper is "How does the legal arrangements of human rights crime find its legitimacy within the law enforcement concept as an extraordinary crime?"

\section{The Objective of Research:-}

The objective of this research is to understand the essence of the human rights in law enforcement, in order to construct a legal protection for human rights violations which has legitimacy within the judiciary system, as an extraordinary crime.

\section{Method of Research:-}

The type of research used in this paper is a normative research. This research reviewing the legal arrangements of human rights crime as an extraordinary crime. Beside to conducting interviews with sources, ${ }^{6}$ The data being used include secondary data consisting of primary law materials in the form of laws and regulations, tertiary law materials in the form of reference books, opinion of experts, and the outcomes of previous research, as well as tertiary law materials in the form of language dictionaries and Black's Law Dictionary.

\section{Research Outcomes and Discussion:- Form of Crimes against Human Rights:-} In the early analysis, according to Titon, ${ }^{7}$ that human rights violations can be done in two forms, namely by commission (actions to do) by the state or other parties, or by omission (action to do nothing) by the state. Human rights violations by the state, either by commission or by omission, it can be seen from the failure of the state to meet four different types of obligations, among others: ${ }^{8}$

\section{The Obligation to Respect:-}

This obligation requires the state and the agent or agents to never take action that would violate the integrity of indivindu or group or infringement on their freedom. For examples are extrajudicial killings, detention nonprosedural and others.

\section{The Obligation to Protect:-}

This obligation requires the state and the agent or agents perform any act aimed in order to protect citizens and groups indivindu and prevent human rights violations against them by other parties. Examples of state failure in carrying out this obligation, among others, in the form of state failure to act when an attack by a group of people to another group.

\section{The Obligation to Fulfil:-}

This obligation requires the state to take adequate measures in providing opportunity legally to all parties as citizens, to achieve the satisfaction of what he need, which can't be met by personal effort. For examples, the failure of the state to provide healthcare facilities or basic education facilities for the people.

\section{The Obligation to Promote:-}

This obligation requires the state to increase public awareness of basic rights that they and their enforcement mechanisms. Examples of violation of this obligation is that the government in conducting socialization and advocacy in the event of a violation of the basic rights.

Disagreements regarding human rights violations which can only be done by the state and its agents or can also be done by non-government units still exist at the moment. When looking at a series of murders, certainly can not deny

6 The authors emphasize that the interview is merely confirmation (affirmation; legalization; justification) and as such or as a comparison only. The interview does not affect the framework that the authors use sources of law as a basis for this research.

7 Titon, Op.Cit., page 7-9

$8 \quad$ Lilian Chenwi, "Strenghening the legal Status of Economic, Sosial and Cultural Rights in the Constitution and National Legal System: Passibilities and Challenges (An Overviw of the African Experience)', National papers presented in the seminar "Towards an Effective Protection and Monitoring on Economic, Social and Cultural Rights in Indonesia," PUSHAM UII, Yogyakarta, April 16-17, 2007, page 3 
that it is the human rights abuses, even though that conduct is not a state and its agents. Instead, those who argue that human rights violations should always be attached to the state, see the murders as a form of government's failure to fulfill its obligation to protect its citizens.

Modern human rights law developed out of customs and theories that established the rights of the individual in relation to the state. In terms of serious violations of human rights, the state must be responsible as well as the two parties, namely the party responsible for upholding human rights on the one hand, and is responsible for the abuses that have been carried out either by commission or by ommision by the individual on behalf of the state.

Jamil Salmi, ${ }^{9}$ related human rights violations describes how all forms of human rights violations that occurred in the end is good concerning the state's obligation to uphold human rights as well as those who should be held responsible for violations occurred. He gives the meaning of violence as a form of human rights violations in the context of broad and divides it into four major categories, as mentioned on Table 1 below:

Table 1:- The meaning of violence as a form of human rights violations.

\begin{tabular}{|c|l|l|}
\hline No. & \multicolumn{1}{|c|}{ Type of Action } & \multicolumn{1}{c|}{ Describes } \\
\hline 1 & Direct Violence & $\begin{array}{l}\text { The violence which refers to acts of physical or psychological attack } \\
\text { someone in person, such as murder, forced expulsion, rape and others, } \\
\text { all of which lead to human rights violations of the most basic, namely } \\
\text { the right to life }\end{array}$ \\
\hline 2 & Indirect Violence & $\begin{array}{l}\text { Jeopardize human, even sometimes until the threat of death, but it } \\
\text { does not involve a direct relationship between the victim and the } \\
\text { responsible party. }\end{array}$ \\
\hline 3 & Repressive Violence & $\begin{array}{l}\text { Associated with the revocation of basic rights, in addition to the rights } \\
\text { to survival and the right to be protected from pain and suffering. }\end{array}$ \\
\hline 4 & Alternative Violence & $\begin{array}{l}\text { The violence which refers to the revocation of rights indivindu higher, } \\
\text { such as the right mental growth, cultural, or intellectual rights. }\end{array}$ \\
\hline
\end{tabular}

The fourth type of violence has the potential to be done by the state which has the highest authority, although it can also be done by indivindu or group. In this regard, once again, the state faced in the duty as law enforcement and human rights, as well as well as those who should be responsible as the perpetrator, if it is proved done by the officials on behalf of the state.

\section{The Concept of Human Rights Crime as an Extraordinary Crime:-}

The terms of 'extraordinary crime' in Indonesia still has many interpretations and there is no standardization of raw, in a sense, what kind of crime that deserves to be included in the category of extraordinary crime. According to Muladi who tried to put forward some of the rationale for grouping an extraordinary crime. In the views of Muladi, the crime is very kriminogen and viktimogen and potentially to harm the interests of various dimensions, from the security order, systematic or organized, threatening political stability, future development and others. ${ }^{10}$

Zainal Abidin ${ }^{11}$ based on Muladi's opinion, added that in accordance with the principle of 'Intent Court', particularly the universal principle that it is impossible to treat severe violation of human rights as an ordinary crime and the universal qualification of the crime against humanity. Based on the above information, can be formulated that serious crimes against human rights is an extraordinary crime because it has the specificity as described below:

First, serious human rights crimes are crimes against humanity against the background of motive power, carried out in a systematic and widespread. Second, serious human rights crimes resulted in the rending of the conscience of humanity, because of the enormity of the impact. Third, serious human rights crimes is a betrayal of the largest man on humanity. Fourth, human rights resulted in the emergence of serious crimes of terror, anxiety and fear in the

9 Jamil Salmi. (2005). Violence and Democratic Society; Hologonisme dan Masyarakat Demokrasi, First edition. Yogyakarta: Pilar Humania, page 31-43.

${ }^{10}$ Ibid.

11 Zainal Abidin. (2005). Pengadilan Hak Asasi Manusia, The course reading material in the series of human rights for lawyers X Year 2005. Elsam, page 3 
community, and can eliminate the public trust in the State. Fifth, serious human rights crimes is recognized internationally as the most serious crimes and even became an international jurisdiction if the settlement can not be resolved at the national level.

Based on the legal construction above, clearly states that serious crimes against human rights are included as an extraordinary crime. The crime has special characteristics and payload, which is not the same and even more than the formulation of the evil that exists in the Criminal Code at the national level. Therefore, the handling of the cases was incredible and special has become a logical consequence to be included as an extraordinary crime.

The international community has recognizes four types of serious human rights violations, the international jurisdiction, so that all countries that respect human rights can prosecute through the International Criminal Court (ICC). The fourth such crimes in the Rome Statute of the International Criminal Court in 1998 in Rome which includes, crimes of genocide, crimes against humanity, war crimes, and the crime of aggression. ${ }^{12}$ At the national level, Indonesia only adopt two types of serious human rights crimes, both the crime of genocide and crimes against humanity, as stipulated in the Law No. 26 Year 2000 regarding Human Rights Court.

\section{Conclusion:-}

Modern human rights law developed out of customs and theories that established the rights of the individual in relation to the state. Legislation concerning serious crimes of human rights, both as ius constituendum and ius constitutum, still needs to be improved, especially in the implementation of human rights on judiciary system. As it turns out in practice, however, it has certain weaknesses.

Recognized or not, serious human rights violations such as crimes against humanity in practice have occurred in Indonesia. Indonesian authority need to encourage a more serious law enforcement officers in law enforcement gross human rights abuses, lest completeness of the laws and the agencies not only as "cosmetic" of human rights. People really looking forward to the government in terms of the law enforcement of human rights, especially on the "political will" of the government to upholds human rights as a constitutional rights.

\section{References:-}

1. Jamil Salmi. (2005). Violence and Democratic Society; Hologonisme dan Masyarakat Demokrasi, First edition. Yogyakarta: Pilar Humania.

2. Lilian Chenwi. (2007). Strenghening the legal Status of Economic, Sosial and Cultural Rights in the Constitution and National Legal System: Passibilities and Challenges (An Overviw of the African Experience). National papers presented in the seminar "Towards an Effective Protection and Monitoring on Economic, Social and Cultural Rights in Indonesia,” PUSHAM UII, Yogyakarta, April 16-17, 2007.

3. M. M. Billah. (2003).Tipologi dan Praktek Pelanggaran hak asasi manusia di Indonesia. Papers prepared for and presented at the National Legal Seminar VIII Year 2003 with the theme "Law Enforcement in the Era of National Sustainable Development" Legal Development Agency Nasinal Ministry of Justice and Human Rights RI, Denpasar, July 14-18, 2003.

4. Margaret M. DeGuzman. (2011). Crimes against Humanity. Research Handbook on International Criminal Law, Bartram S. Brown, ed., Edgar Elgar Publishing.

5. Romli Atmasasmita. (2000). Pengantar Hukum Pidana Internasional, Jakarta: Refika Aditama.

6. Titon Slamet Kurnia. (2005). Reparasi terhadap Korban Pelanggaran HAM di Indonesia. Jakarta: PT Citra Aditya Bakti.

7. Todung Mulya Lubis. (1994). In Search of Human Rights: Legal-Political Dilemmas of Indonesia's New Order, 1966-1990.

8. Zainal Abidin. (2005). Pengadilan Hak Asasi Manusia. The course reading material in the series of human rights for lawyers X Year 2005. Elsam.

\footnotetext{
${ }^{12}$ Part, Article 5, point (1) Rome Statuta of The Intent Court.
} 